\title{
Phosphatocopine arthropods
}

\author{
Frederick R. Schram \\ Zoological Museum, University of Amsterdam, Mauritskade 57, 1092 AD Amsterdam, Netherlands
}

Review of: Morphology, ontogeny and phylogeny of the Phosphatocopina (Crustacea) from the Upper Cambrian "Orsten" from Sweden, Andreas Maas, Dieter Waloszek and Klaus J. Müller. Fossils and Strata 49: 1- 238. Taylor and Francis, Oslo, Norway. ISSN 0300-9491.

For anyone interested in the early history and evolution of arthropods, one simply cannot get along without reference to the series of works that have been appearing since the 1970s by Dieter Waloszek and Klaus Müller on the Cambrian Orsten fossils. Of particular importance in this regard is the sequence of exceptional monographs published in Fossils and Strata. This volume is the most recent in that series.

The Phosphatocopina were first recognized by Müller (1964) and placed among the ostracodes. With little more than the bivalved shell known at that time, this was understandable. Any small bivalved critters found in the Cambrian were automatically considered to be ostracodes in those days. In this instance, the phosphatocopines were believed to be related to another non-descript Cambrian group, the Bradoriina. It was only with the discovery of the Swedish "stink stones," or Orsten, that people began to discover the animals inside the bivalved shells. Other localities came to light, and even the internal anatomy of bradoriines revealed itself. Subsequently, Müller and Walossek (1991) came to doubt the ostracode affinities of phosphatocopines, and this began a reassessment of all the tiny Cambrian bivalved arthropods. It became evident that the only thing all these animals shared in common was a bivalved shell. The animals inside were all different from each other. Presently, there is even doubt in some circles as to whether the Ostracoda form a monophyletic group. The whole Cambrian radiation of crustaceomorph forms is now being reassessed. Needless to say, understanding the phophätocopines is proving to be critical towards understanding the phylogenetic relationships among the earliest crustaceomorph arthropods.

Hence, it is of great interest that we now have such an imposing and information packed monograph on this group. Maas and his co-authors have done a remarkable job not only providing a review of some of the soft anatomy of phosphatocopines inside the bivalved shell, but also laying out an impressive amount of data that deals with the ontogeny of these interesting creatures.

In this monograph, after a short overview of the Orsten area on Gotland, Sweden and a summary of study techniques, the hard and soft anatomy of the phosphatocopines is outlined. Hesslandona unisulcata, due to the wealth of extremely well-preserved material, serves as a model organism for the group. As with many of the Orsten arthropods, the wealth of detail never ceases to amaze, and in some instances it almost deceives. For example, the image in Plate $12 \mathrm{C}$ had me thinking for a minute that a SEM of minute sub-setules of a living form was included for comparative purposes before I realized this photo was a detail arriving out of the Cambrian.

Some 2,500 specimens were examined for this monograph, and most of these proved to be growth stages. Hesslandona unisulcata goes through 8 
stages before achieving the final form. The revealed details of limb ontogeny is staggering. We now know more about the development of Hesslandona unisulcata than we do about that of most living ostracodes. The earliest stage in the ontogenetic sequence begins with an animal possessing 4 sets of limbs. Thus, phosphatocopines lack a nauplius larva, i.e., a stage with 3 sets of limbs, and are excluded from membership in the crown group crustaceans. The variations in ontogeny of various species of Hesslandona are laid out in great detail. For some species, only 5 stages are recognized, for others it is not yet possible to separate discrete stages.

Through some 130 pages and 33 plates of SEMs the reader is carried through a survey of the generic level and species biodiversity of the phosphatocopines. This reviewer never really appreciated the variability of form in this group until reading this section. Detailed as this monograph is, there is more information yet to come. The authors indicate that in a future publication, the amount of variability in limb morphology between various species will be laid out in a phylogenetic approach.

Nevertheless, the authors here did undertake a preliminary cladistic analysis of the phylogeny of phosphatocopines. What marks this volume as a real advance in Orsten arthropod studies is the delineation of a well-defined set of characters in an explicit data matrix. The scoring of characters for the taxa employed is clear for all to examine, and the analysis is undertaken with multiple out-groups. A modicum of phylogenetic structure emerges, especially within the genus Hesslandona. The phylogeny is meant as a framework to assess in the future other less well-preserved phophatocopipes, but each taxon and branch point in the tree is defined with an array of characters that lay out the possible evolution of phosphatocopine form. My only problem here was in trying to understand what the authors were doing in erecting the "Dorospinata." This denotes a clade whose sister taxon is Hess- landona unisulcata. Is Dorospinata a genus? a subgenus? a species group? There is phylogenetic structure within the cladogram of this entity, whatever it is. Nevertheless, one very effective thing the authors do is to compare the results of their cladistic analysis with the evolutionary systematic taxonomy developed through the years in older papers by other authors. As a result we can clearly see why old families like Filitidae and Vestrogothiidae have problems; they are not monophyletic.

The final section on crustacean phylogeny is less satisfactory - but not without merit. It serves to clearly outline what the phosphatocopine ground pattern is. This phylogeny is not tied, however, to an explicit set of characters and a data matrix. Beyond defining the relationship of the target taxon with the crown crustaceans, it does not attempt to define relationships in the stem crustaceomorphs used here.

This is a fine piece of work. Maas and his coauthors can be justly proud. I for my part will look forward to the second monograph on soft anatomy details. Until then, we have a substantial piece of work at hand by which we can try to understand the other tiny Cambrian bivalved arthropods. This is a must have volume for anyone interested in the early history of the arthropods.

\section{References}

Müller KJ. 1964. Ostracoden (Bradorina) mit phosphatischen Gehäusen aus dem Obercambrium von Schweden. Neues Jahrbuch der Geologie und Paläontologie, Abhandlungen 121: 1-46.

Müller KJ, Walossek D. 1991. Ein Blick durch das "Orsten" - Fenster in die Arthropodenwelt vor 500 Millionen Jahren. Verhandlungen der Deutschen Zoologischen Gesellschaft 84: 281-294.

Received: 29 October 2003 